\title{
Sophie de Grouchy: filozofia oparta na polemice ${ }^{1}$
}

\author{
Anna Markwart \\ https://orcid.org/0000-0002-2449-1292
}

Sophie de Grouchy była tłumaczką Teorii uczuć moralnych Adama Smitha na język francuski. Do swego przekładu dołączyła Listy o sympatii, w których zwróciła uwagę na podstawowy jej zdaniem brak w dziele Smitha: niewyjaśnienie źródeł sympatii. Jej Listy nie tylko przedstawiają poglądy myślicielki na tę kwestię, lecz także zawierają jej rozważania na temat sympatii, krytykę instytucji itp. Artykuł ma na celu przedstawienie sylwetki de Grouchy, scharakteryzowanie jej teorii sympatii oraz wskazanie, iż Listynie są jedynie komentarzem do Teorii Smitha, lecz zawierają poglądy filozoficzne często rozbieżne z tymi, które prezentował Szkot.

Słowa kluczowe: Sophie de Grouchy, Adam Smith, sympatia

Marie Louise Sophie de Grouchy $\left(1764^{2}-1822\right)$, określana jest zwykle jako Sophie de Grouchy lub Sophie de Condorcet (na okładce swego dzieła używa obu

ANNA MARKWART, doktor, Instytut Filozofii, Uniwersytet Mikołaja Kopernika w Toruniu; adres do korespondencji: Instytut Filozofii UMK, Fosa Staromiejska 1a, 87-100 Toruń; e-mail: markwart.anna@gmail.com

${ }^{1}$ Badania zostały sfinansowane ze środków Narodowego Centrum Nauki, przyznanych w ramach finansowania stażu po uzyskaniu stopnia naukowego doktora na podstawie decyzji numer 2016/20/S/HS1/00071.

${ }^{2}$ Karin Brown, „Introduction: The Letters, Their Author, and Her Times”, w: Sophie de Grouchy, Letters on sympathy (1798) : a critical edition, red. Karin Brown (Philadelphia: American Philosophical Society, 2008), VII; Antoine Guillois, La Marquise de Condorcet. Sa Famille, son Salon, ses Amis 1764- 
nazwisk: Sophie de Grouchy, wdowa po Condorcecie). Doceniana była przede wszystkim jako autorka przekładu Teorii uczuć moralnych Adama Smitha na język francuski; jej zainteresowanie myślą Smitha nie było jedynym istotnym obszarem inspiracji. Jej poglądy zostały ukształtowane przez liczne lektury, rozmowy oraz życie u boku Nicolasa markiza de Condorcet, filozofa, który doceniał jej przenikliwą inteligencję. Salon, który prowadzili, przyciągał wielkie umysły epoki.

Do jej tłumaczenia Teorii dołączane były napisane przez nią Listy o sympatii (Les Lettres sur la sympathie). Chociaż skupia się w nich na pojęciu charakterystycznym dla filozofii moralnej Smitha, uwagi de Grouchy wykraczają znacząco poza zadania komentarza czy dodatku. Myślicielka, krytykując Szkota, przedstawia własne poglądy na źródła sympatii, dodając również liczne uwagi i przemyślenia dotyczące kwestii społecznych i argumentuje za swoimi tezami.

Chociaż już samym pojęciem „sympatii”, charakterystycznym dla filozofii moralnej szkockiego Oświecenia, Sophie de Grouchy sięga do tradycji filozoficznej, z której wywodził się Smith, w jej poglądach wyraźnie rezonuje także tradycja francuskiego Oświecenia ${ }^{3}$. Artykuł ten ma na celu nie tylko przedstawienie sylwetki ${ }^{4}$ Sophie de Grouchy, lecz także wprowadzenie do analizy jej teorii sympatii. Jak sądzę, Listy o sympatii przedstawiają oryginalną koncepcję i nie są jedynie powtórzeniem czy krytyką, lecz raczej ciekawym uzupełnieniem, rozwinięciem lub niekiedy nawet zaprzeczeniem poglądów Adama Smitha dotyczących współodczuwania.

1822 (Paryż: Paul Ollendorff, 1897), 8. Autor wspomina, że Robinet podał jako datę narodzin Sophie de Grouchy wrzesień 1766 roku, co jest niemożliwe, argumentując to znanymi listami oraz narodzinami jej młodszego brata w październiku 1766 roku.

${ }^{3}$ Daniel Dumouchel uważa, że samo poszukiwanie „pierwszej przyczyny” sympatii bardziej przypomina filozofię Condillaca niż Szkotów [Daniel Dumouchel „Une éducation sentimentale: sympathie et construction de la morale dans les Lettres sur la sympathie de Sophie de Grouchy", w: Les 'Lettres sur la sympathie' (1798) de Sophie de Grouchy, marquise de Condorcet, red. Marc André Bernier i Deidre Dawson (Oxford: Voltaire Foundation, 2010), 139].

${ }^{4}$ Autorka wstępu do angielskiego przekładu Listów o sympatii zwraca uwagę, że Sophie de Grouchy do niedawna była niemal nieznana i rzadko dyskutowana w świecie anglosaskim, nie tylko jako autorka dzieła filozoficznego, ale nawet jako ważna postać w życiu Condorceta. Jednocześnie przez współczesnych sobie była doceniana (Brown, „Introduction,” XIII-XIX). Sytuacja zaczęła się zmieniać po publikacji angielskiego przekładu Listów w 2008 roku oraz po pojawieniu się pod koniec XX wieku pierwszych artykułów naukowych w języku angielskim poświęconych jej filozofii. Dlatego ważne wydaje się nie tylko analizowanie poglądów filozoficznych Sophie de Grouchy, lecz także przedstawienie jej sylwetki i tła powstania przekładu Teorii uczuć moralnych. 


\section{Kim była Sophie de Grouchy? ${ }^{5}$}

Sophie de Grouchy urodziła się w 1764 roku jako córka Francoise Jacques markiza de Grouchy i Marie-Gilberte-Henriette Fréteau, jako najstarsza z trójki rodzeństwa. Przekazy, którymi dysponujemy, przedstawiają ją jako inteligentną, piękną i zdolną dziewczynę, która już w wieku nastoletnim czytała Marka Aureliusza, organizowała czas rodzeństwu i pomagała biedniejszym dzieciom mieszkającym w okolicy. W 1784 roku rozpoczęła edukację w szkole klasztornej w Neuville - nie odnalazła się w niej jednak, i to mimo tego, że reguła, jak piszą biografowie, nie była nadmiernie surowa. Uczęszczała na zajęcia, czytała Voltaire’a i Rousseau. Dosyć szybko miejsce Sophie w szkole zajęła jej młodsza siostra Charlotte, zaś sama Sophie de Grouchy powróciła do majątku rodziców.

W 1786 roku wyszła za mąż za Nicolasa de Condorcet, znacznie od niej starszego filozofa. Jak twierdzą biografowie, byli małżeństwem kochającym się i zgodnym, w którym było „wiele uczuć, wiele porywów serca i entuzjazmu ducha”. W maju 1790 roku urodziła im się córka, Alexandrine-Louise-Sophie, nazywana Elisą. Niebagatelną rolę odegrały tu poglądy filozofa, który popierał równość płci i przyznanie praw wyborczych kobietom, traktując małżonkę jako równorzędnego partnera dyskusji ${ }^{7}$. Wzajemnie wpływali na swoje poglądy: „nie ma wątpliwości, że Sophie była źródłem inspiracji dla markiza Condorcet. Miała swój udział w jego myśli i pismach przez cały okres małżeństwa"8.

Żywą debatę intelektualną podtrzymywano także w Salonie, który w Hôtel des Monnaies w Paryżu prowadzili markiza i markiz de Condorcet. Gościli nie tylko francuskich myślicieli, ale też Brytyjczyków i Amerykanów. Bywali tam Robert Turgot, Olympe de Gouges, Benjamin Franklin, Thomas Paine. Pojawiły się nawet sugestie, że ich Salon mógł odwiedzać Adam Smith w czasie swej podróży do Francji. Niestety, takie spotkanie najprawdopodobniej nie nastąpiło, co

${ }^{5}$ Fragment ten powstał przede wszystkim na podstawie dwóch źródeł (Brown, „Introduction”, Guillois, La Marquise de Condorcet). Odwołania w tym fragmencie będą pojawiać się przede wszystkim w odniesieniu do źródeł wykraczających poza przywołane tu dwa podstawowe.

${ }^{6}$ Guillois, La Marquise de Condorcet, 64.

${ }^{7}$ Brown, „Introduction”, XXI; Deidre Dawson, „Love, Marriage and Virtue: Mary Wollstonecraft and Sophie de Grouchy, marquise de Condorcet, Respond to The Theory of Moral Sentiments', Adam Smith Review7 (2014): 38-39.

${ }^{8}$ Brown, „Introduction”, XXI. O ile nie zaznaczono inaczej, wszystkie fragmenty cytowane pochodzące z tekstów w języku angielskim lub francuskim są w przekładzie własnym. 
w swym artykule wykazała Simona Pisanelli'. Sophie de Grouchy i Nicolas de Condorcet uczestniczyli w prowadzeniu przybytku znanego pod nazwą Paris Lycée - służącego edukacji dorosłych, spotkaniom literackim i dyskusjom naukowym. Obok Condorceta lekcje prowadzili tam: Harpe, Garat, Marmontel, Lacroix, Fourcroy, Parcieux.

$\mathrm{Na}$ życiu Sophie de Grouchy piętno odcisnęła rewolucja francuska, którą, początkowo, oboje z mężem popierali. Ukrywanie się, uwięzienie, a następnie nie do końca wyjaśniona śmierć Condorceta sprawiły, że Sophie de Grouchy zmuszona była samodzielnie utrzymywać siebie, swoją córkę i siostrę. Kupiła sklep z bielizną, który przynosił jej pewien dochód, malowała także obrazy na zamówienie i odwiedzała więźniów, przynosząc im wiadomości od rodzin. Przeprowadziła także procedurę rozwodową, aby uchronić swoją córkę przed zagrożeniem ze strony stronnictwa Robespierre’a oraz ocalić majątek. Choć po śmierci Condorceta była w innych związkach, nigdy więcej już nie wyszła za mąż.

Po upadku rewolucji francuskiej de Grouchy odzyskała dom i część majątku. Ponownie zaczęła prowadzić Salon, kontynuując interesujące dyskusje. Jednym z częstszych gości Salonu był Pierre Cabanis - mąż Charlotte, siostry Sophie. Odgrywała także znaczącą rolę w procesie wydawania dzieł Condorceta (w tym napisanego w trakcie ukrywania się Szkicu obrazu postępu ducha ludzkiego poprzez dzieje), do których prawa sprzedała Georgowi Heinrrichowi Sievekingowi ${ }^{10}$. Oddała się także tłumaczeniu Teorii uczuć moralnych na język francuski oraz pisaniu traktatu poświęconego edukacji, będącej ważnym tematem jej rozważań. Niestety, ten ostatni zaginął.

\section{Przekład Teorii uczuć moralnych}

Tłumaczenie Teorii uczuć moralnych przygotowane przez Sophie de Grouchy nie było pierwszą próbą przekładu tego dzieła na język francuski. Wcześniej wydane zostały dwa (z trzech, które powstały - prace nad ostatnim zostały wstrzymane ze względu na wydanie drugiej wersji przekładu). Pierwszy raz Francuzi

${ }^{9}$ Simona Pisanelli, „Adam Smith and the Marquis de Condorcet. Did they really meet?”, Iberian Journal of History of Economic Thought 2, nr 1 (2015): 21-35, DOI: 10.5209/rev_IJHE.2015.v2.n1.49771

${ }^{10}$ Catriona Seth, „Sophie de Grouchy-Condorcet's translation of Adam Smith's Theory of Moral Sentiments," Adam Smith Review 7 (2014): 18, DOI: 10.4324/9780203070727 
mieli okazję zapoznać się z dziełem Smitha w tłumaczeniu na ich język już w 1764 roku (pierwsze wydanie angielskie to 1759 rok - przekładu dokonano zatem bardzo szybko, co niewątpliwie świadczy o popularności szkockiego filozofa po drugiej stronie kanału La Manche). Marc-Antoine Eidous przełożył Teorię, nadając książce tytuł Métaphysique de l'âme, ou Théorie des sentiments moraux (Metafizyka duszy, lub Teoria uczuć moralnych) - sam Smith nie był zadowolony z tego przekładu ${ }^{11}$. Drugą - lepiej przyjętą wersją - była ta przygotowana przez Jean-Lousia Blaveta (1774-1775) ${ }^{12}$.

W naturalny sposób rodzi się zatem pytanie, dlaczego Sophie de Grouchy podjęła się zadania przetłumaczenia Teorii uczuć moralnych na język francuski po raz kolejny. Komentatorzy wskazują na różne czynniki: od finansowych ${ }^{13}$ (po śmierci męża szukała źródeł dochodu pozwalających utrzymać rodzinę) po merytoryczne. Na te ostatnie wskazywała sama myślicielka już na pierwszych stronach Listów o sympatii, pisząc: „Chociaż nie czytałam wtedy jeszcze Teorii uczuć moralnych Smitha: spotkałam się ze złymi opiniami na temat francuskiego tłumaczenia tego słynnego dzieła, a nie rozumiałam angielskiego na tyle, by przeczytać oryginał. Ostatecznie ośmieliłam się podjąć tego zadania, jednak zamiast podążać za ideami filozofa z Edynburga, pozwoliłam rozwinąć się swoim"14.

Jak zauważa Catriona Seth, podjęcie się przekładu Teorii uczuć moralnych mogło być także swoistym pocieszeniem oraz hołdem pamięci Condorceta, który planował wydanie zbioru uwag mających towarzyszyć francuskiemu tłumaczeniu

${ }^{11}$ Michaël Biziou, „French translations and re-translations of Smith’s Theory of Moral Sentiments: the unbearable lightness of (re)translating", Adam Smith Review 8 (2015): 56, DOI: 10.4324/9781315737195. Biziou zwraca uwagę, że mylący tytuł w rzeczywistości mógł być swoistym „chwytem marketingowym”, który miał zachęcić francuskiego czytelnika i przybliżyć mu tematykę dzieła Smitha - szkockie oświecenie, w obrębie którego powstawała Teoria uczuć moralnych, skupiało się na innych pojęciach niż oświecenie francuskie.

${ }^{12}$ Tamże, 57. Blavet uważał, że przekład jest dosłowny, dokładny i uniwersalny, nie biorąc pod uwagę różnic kulturowych.

${ }^{13}$ Catriona Seth, „Un double service rendu à la postérité: la Théorie des sentiments moraux par Adam Smith, suivie des Lettres sur la sympathie”, w: Les 'Lettres sur la sympathie' (1798) de Sophie de Grouchy, marquise de Condorcet, red. Marc André Bernier i Deidre Dawson (Oxford: Voltaire Foundation, 2010), 129, 131.

${ }^{14}$ Sophie de Grouchy, ,Lettres sur la sympathie”, w: Les 'Lettres sur la sympathie' (1798) de Sophie de Grouchy, marquise de Condorcet, red. Marc André Bernier i Deidre Dawson (Oxford: Voltaire Foundation, 2010), 30. 
Badań nad naturą i przyczynami bogactwa narodó $w^{15}$ - książce Smitha poświęconej problematyce ekonomicznej. Sama myślicielka podziwiała filozofię Smitha. Istotną rolę odegrało zapewne przekonanie, że Teoria uczuć moralnych zasługuje na dobry przekład ${ }^{16}$. Sophie de Grouchy nie tylko przełożyła tekst na język francuski, ale także weszła z nim w dialog, dołączając do niego Listy o sympatii. Dostrzegała niektóre słabości tekstu Smitha. Jednocześnie tworzyła w okresie odbudowywania społeczeństwa po krwawej rewolucji, co wymagało nieco innego spojrzenia niż to, które proponował Szkot. Przekład dokonany przez Sophie de Grouchy nie jest idealny - jak zwrócił uwagę Michaël Biziou ${ }^{17}$ niektóre słowa są przetłumaczone niewłaściwie, inne ominięte. Chociaż myślicielka wykonała świetną pracę translatorską, niekiedy okazuje się, że proponowane przez nią zdania mogą być mylące i sugerować błędne interpretacje. Częściowo wynikać to może z niewystarczającego zrozumienia tekstu lub intencji Smitha, częściowo zaś z kontekstu, w którym jej przekład powstawał, a co za tym idzie: podkreślania konieczności edukowania i wychowywania ludzi. Alexander Broadie zaznaczył: „Uzasadnione jest założenie, że Sophie de Grouchy uważała, iż lepsze zrozumienie Teorii uczuć moralnych może przyczynić się do zdrowienia społeczeństwa; w takim wypadku musimy traktować jej tłumaczenie i komentowanie Teorii uczuć moralnych jako część kampanii moralnej prowadzonej w podpowiedzi na sytuację krytyczną w sensie moralnym, społecznym i, oczywiście, politycznym" ${ }^{\text {"18 }}$. Niekiedy jednak de Grouchy dokonuje zmian właśnie po to, by oddać dokładniej intencje Smitha - nie zawsze przekład „jeden za jeden” spełnia swoją rolę, niekiedy potrzebne jest dorzucenie uzupełnienia, czy omówienie pojęcia - z braku właściwego słowa w języku francuskim ${ }^{19}$. Czasem też inaczej konstruuje się zdania w języku francuskim niż angielskim. Dlatego też tłumaczka wprowadza zmiany w szyku, niekiedy zmienia np. liczbę mnogą na pojedynczą i odwrotnie.

Przekład autorstwa Sophie de Grouchy spotkał się z ciepłym przyjęciem i pozytywnymi recenzjami. Tłumaczka chwalona była zarówno za jakość pracy, jak i za styl. Czasem jej przekład może wydawać się nawet zbyt elegancki i ugładzony

\footnotetext{
${ }^{15}$ Seth, „Sophie de Grouchy-Condorcet's translation”, 18.

${ }^{16}$ Alexander Broadie, Agreeable Connexions: Scottish Enlightenment Links with France (Edinburgh: Birlinn, 2012), 116.

${ }^{17}$ Biziou, „French translations and re-translations”, 60-61. Biziou podaje konkretne przykłady pomyłek i przekłamań.

${ }^{18}$ Broadie, Agreeable Connexions, 117.

${ }^{19}$ Seth, „Un double service rendu à la postérité”, 135.
} 
w stosunku do języka oryginału ${ }^{20}$. Wyrazy aprobaty wyrazili, między innymi, Madame de Stael i Morellet ${ }^{21}$. Współczesna wersja, która zastąpiła tłumaczenie Sophie de Grouchy jako obowiązujące we Francji, powstała dopiero w 1999 roku. Przekład przygotowany w 1798 roku był wznawiany wielokrotnie jeszcze w XIX wieku (1820, 1830 i 1860). Za każdym razem wraz z dołączonymi do niego Listami o sympatii ${ }^{22}$.

\section{Krótko o Listach o sympatii}

Należy zwrócić uwagę, że chociaż na okładce przekładu Teorii uczuć moralnych pojawia się informacja, iż towarzyszą mu właśnie Lettres sur la Sympathie (Listy o sympatii - i to określenie jest powszechnie stosowane jako tytuł dzieła), to jednak pełny tytuł pojawiający się na początku tekstu brzmi: Lettres a $C^{* * *}$, sur la Théorie des Sentiments Moraux (Listy do $C^{* * *}$ o teorii uczuć moralnych). Podczas gdy tytuł skrócony dużo lepiej oddaje treść Listów, ten pełny wyraźnie odwołuje się do książki Smitha, osadzając słowa Sophie de Grouchy jeszcze mocniej w kontekście filozofii szkockiego myśliciela.

Warto zaznaczyć, że, zdaniem niektórych komentatorów, nie jest wcale oczy-

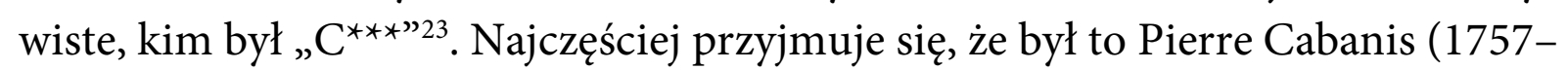
1808), mąż Charlotte, siostry Sophie de Grouchy, lekarz i filozof, opierający idee problematykę uczuć i moralności na badaniach dotyczących ciała, potrzeb, działania instynktów, tworzący filozofię materialistyczną, podkreślający istotną rolę układu nerwowego. Takie założenie pojawiło się już w wydaniu Listów z 1830 roku, gdzie „C $\mathrm{C}^{\star * * ”}$ zamieniono na „Cabanis”. Druga hipoteza głosi jednak, że tajemniczym „ $\mathrm{C}^{\star * * ”}$ mógł być sam Condorcet, który tak właśnie podpisywał niektóre pisma.

Dzieło Sophie de Grouchy składa się z ośmiu listów, w których przedstawia ona swoje poglądy. Punktem wyjścia rozważań jest przekonanie, że człowiek jest niezwykle interesującym obiektem refleksji. Myślicielka szybko zwraca uwagę na to, czego wyraźnie brakuje jej w Teorii uczuć moralnych: „[...] przedmiotem

\footnotetext{
${ }^{20}$ Tamże, 133.

${ }^{21}$ Seth, „Sophie de Grouchy-Condorcet's translation”, 19-20.

${ }^{22}$ Broadie, Agreeable Connexions, 116.

${ }^{23}$ de Grouchy, „Lettres sur la sympathie”, 29.
} 
pierwszych rozdziałów jest sympatia. Smith ograniczył się do stwierdzenia jej istnienia i do pokazania jej głównych skutków: żałowałam, że nie ośmielił się sięgnąć dalej, zbadać jej pierwszej przyczyny, wreszcie pokazać, w jaki sposób sympatia musi przynależeć każdej istocie wrażliwej i zdolnej do refleksji”24.

\section{Źródła sympatii}

Definicja sympatii, jaką proponuje Sophie de Grouchy, różni się od tej, którą podaje Adam Smith. Już w pierwszym rozdziale Teorii uczuć moralnych autor zaznacza, że „Współczucie i litość - oto stosowne słowa do oznaczania naszego współodczuwania ze smutkiem innych. Słowo »sympatia» (sympathy), choć znaczyło zapewne początkowo to samo, można obecnie bez popełnienia większego błędu użyć do oznaczenia naszego współodczuwania z wszelkim doznaniem emocjonalnym” 25 (fellow-feeling with any passion whatever ${ }^{26}$ ). Terminów „sympatia” i „współodczuwanie”, „współdoznawanie” filozof używa wymiennie. De Grouchy natomiast definiuje sympatię jako „dyspozycję, którą mamy do odczuwania w sposób podobny do drugiego"27 (człowieka). Alexander Broadie podkreśla, że podczas gdy u markizy Condorcet wyraźnie mamy do czynienia z dyspozycją do odczuwania, tak w przypadku Smitha mamy do czynienia z uczuciem ${ }^{28}$ lub - ostatecznie - aktualizacją dyspozycji ${ }^{29}$. Jak twierdzi Broadie: „[...] użycie przez Sophie de Grouchy słowa »dyspozycja« w tym kontekście jest ważne, ponieważ dyspozycje to coś, do czego ludzie mogą zostać wychowani, co może być wzmacniane i doskonalone, zaś problem najbardziej efektywnych form edukacji dla stworzenia sympatyzujących ludzie jest ważnym polem badań w Listach" ${ }^{30}$. Oboje podkreślają

\footnotetext{
${ }^{24}$ Tamże, 30.

${ }^{25}$ Adam Smith, Teoria uczuć moralnych, tłum. Danuta Petsch (Warszawa: PWN, 1989), 8.

${ }^{26}$ Tenże, The Theory of Moral Sentiments (Indianapolis: Liberty Fund, 1982), 10.

${ }^{27}$ de Grouchy, „Lettres sur la sympathie”, 31.

${ }^{28}$ Natomiast Charles Griswold Jr. (Charles L. Griswold Jr., Adam Smith and the Virtues of En-
} lightment (Cambridge: Cambridge University Press, 2009), 78-83, DOI: 10.1017/CBO9780511608964) wprowadza rozróżnienie na sympatię w sensie „technicznym” i w sensie emocji, zaś Hans D. Muller (Hans D. Muller, „Sympathy for whom? Smith's reply to Hume,” Journal of the American Philosophical Association 2, nr 2 (2016): 213, DOI: 10.1017/apa.2016.15) podkreśla, że sympatia emocją nie jest.

${ }^{29}$ Broadie, Agreeable Connexions, 142.

30 Tamże, 142. 
rolę wyobraźni w procesie sympatyzowania, u Smitha jednak jej znaczenie jest kluczowe - współodczuwając stawiamy się na miejscu drugiej osoby, do tego zaś wyobraźnia jest niezbędna.

Sympatia w Teorii uczuć moralnych to nie idealne odwzorowywanie emocji drugiej osoby, ale złożony proces, biorący często pod uwagę okoliczności. Warto zwrócić uwagę, że Smith sympatię pojmował bardzo szeroko - od niemal automatycznych reakcji na czyjeś działanie ${ }^{31}$, przez stawianie się na miejscu drugiej osoby, by wydać sąd moralny, po naturalną sympatię, a niekiedy nawet życzliwość. Myśliciel zauważa, że niekiedy uczucia sympatyzującego będą różnić się od tych doświadczanych przez podmiot działający - świadczyć mogą o tym choćby podane przez niego przykłady współodczuwania ze zmarłymi czy nieświadomymi sytuacji. Sympatia nigdy nie jest prostym kopiowaniem uczuć - według filozofa doświadczenie jest możliwe do przekazania poprzez gesty czy słowa, lecz prywatne i niemożliwe do poznania w pełni, stąd raczej oceniamy sytuację i działania innych niż „przejmujemy” ich uczucia ${ }^{32}$.

Podstawowym zarzutem postawionym Smithowi przez de Grouchy jest brak określenia źródeł sympatii. Rzeczywiście, filozof nie poświęca temu zagadnieniu wiele uwagi. Zauważa jednak: „Że źródłem naszego współodczuwania nieszczęścia innych jest to, że stawiając się w wyobraźni na miejscu człowieka cierpiącego, pojmujemy, co on czuje, albo jesteśmy tym poruszeni, można ukazać $\mathrm{w}$ wielu ewidentnych obserwacjach, jeśli to nie jest oczywiste samo przez się"33. Autorka $\mathrm{Li}^{\text {- }}$ stów źródeł sympatii upatruje w bólu fizycznym. Uważa, że to właśnie sympatię dotyczącą doznań fizycznych trzeba przeanalizować, zanim zacznie się badać sympatię doświadczaną w obliczu zła moralnego. Jak twierdzi: „Każdy ból fizyczny rodzi złożone odczucie w osobie, która go doświadcza. Wytwarza najpierw ból lokalny w części ciała, na którą bezpośrednio działa przyczyna bólu. Dodatkowo wytwarza impresję bólu we wszystkich naszych organach, impresję bardzo różną od bólu lokalnego, która zawsze towarzyszy bólowi, ale która może istnieć bez niego" "34. Ból fizyczny jest zawsze złożony. W dodatku bezpośrednio po jego ustąpieniu można doświadczyć zarówno przyjemności wynikającej z tego, że już

\footnotetext{
${ }^{31}$ Smith, Teoria uczuć moralnych, 6-7.

${ }^{32}$ James R. Otteson, Adam Smith's Marketplace of Life (Cambridge: Cambridge University Press, 2002), 20-21.

${ }^{33}$ Smith, Teoria uczuć moralnych, 6.

${ }^{34}$ de Grouchy, „Lettres sur la sympathie”, 31.
} 
nie boli, jak i ogólnego poczucia nieszczęścia (un sentiment général de malaise, general feeling of malaise), które choć $\mathrm{z}$ bólu wynika, pozostaje $\mathrm{w}$ nas długo po jego ustąpieniu i może być bardzo nieprzyjemne i bolesne dla doświadczającego go.

Kiedy po raz kolejny doświadczymy bólu fizycznego, poczucie to pojawia się ponownie. Nawet jeśli ból jest inny, to ogólne poczucie nieszczęścia może być takie samo lub podobne. Gdy przypominamy sobie ból, którego doświadczyliśmy - powraca również ogólne poczucie nieszczęścia z nim związane. Dokonanie namysłu nad tym, czego doświadczyliśmy oraz wspomnienie bólu (które wymaga działania wyobraźni - nie jest jasne, czy myślicielka łączy wyobraźnię i pamięć w jedną władzę, czy nie ${ }^{35}$ ), które jesteśmy w stanie przywołać, sprawiają, że sympatyzujemy. Oczywiście istotną rolę odgrywa również refleksja, pobudzająca współczucie, przybliżająca do cierpiącego i przypominająca o naszej śmiertelności ${ }^{36}$.

Pojedyncze odczucia bólu (lub przyjemności - Sophie de Grouchy zauważa, że proces sympatyzowania $z$ przyjemnymi odczuciami przebiega podobnie ${ }^{37}$ ), „gdy tylko rozwój naszych zdolności i powtarzane doświadczenie bólu pozwala nam na wytworzenie jego abstrakcyjnej idei, sama ta idea odnawia w nas ogólne wrażenie wytwarzane przez ból we wszystkich naszych organach. Tu zatem pojawia się efekt bólu, który jest następstwem zarówno jego fizycznej, jak i moralnej obecności. Przez moralną obecność rozumiem tu albo ideę bólu, którą daje nam nasza wyobraźnia, albo tę, którą możemy mieć dzięki dostrzeżeniu lub wiedzy o czyimś bólu”38. Zdaniem de Grouchy, trudniej sympatyzować z przyjemnością niż z bólem, ponieważ przyjemność jest mniej intensywna niż ból i z założenia musi być wykluczająca. Jednocześnie obserwatorzy wcale nie chcą być z niej wykluczeni ${ }^{39}$. Pogląd ten odbiega od uwag zawartych w Teorii uczuć moralnych: „Smith stawia przeciwną propozycję i wierzy, że ją uzasadnia stwierdzeniem, iż imitowanie bólu cielesnego niezbyt nas porusza; że takie małpowanie jest raczej zabawne niż budzi współczucie, podczas gdy naśladowanie cierpień moralnych budzi bardziej intensywne impresje w duszy. Czy to dlatego, że sympatyzujemy

\footnotetext{
${ }^{35}$ Broadie, Agreeable Connexions, 147.

${ }^{36}$ de Grouchy, „Lettres sur la sympathie”, 38-39.

${ }^{37}$ Broadie, Agreeable Connexions, 150.

${ }^{38}$ de Grouchy, „Lettres sur la sympathie”, 32.

${ }^{39}$ Tamże, 36.
} 
mniej z człowiekiem, który stracił nogę niż z tym, który stracił kochankę, bo jedno $\mathrm{z}$ tych wydarzeń może być tematem tragedii, a drugie nie?"40.

Co więcej - zdaniem Smitha - istotny jest poziom intensywności przeżycia (bardziej współodczuwamy z małymi radościami i wielkimi smutkami, niż odwrotnie $^{41}$, doznajemy oddźwięku uczuciowego nawet, gdy oznaki rozpaczy są przesadzone, co - w przypadku nadmiernego okazywania radości - owocuje raczej pogardą obserwatorów ${ }^{42}$ ) - który to aspekt autorka Listów pomija. Sympatię ze smutkiem uważa Smith za bardziej uniwersalną w stosunku do tej z radością. Jego zdaniem również dla osoby doznającej uczuć ważniejsze jest to, by inni podzielali smutek i współczuli niż wspólnie się cieszyli. Mimo tego poglądy Szkota znacząco różnią się od tych zaprezentowanych przez tłumaczkę jego dzieła. Filozof podkreślał, że trudno jest współodczuwać z doznaniami fizycznymi - bez względu na to, czy chodzi o ból (podstawowy przecież dla sympatii w teorii de Grouchy), głód, przyjemność, popędy czy namiętnośćc ${ }^{3}$. Według Smitha, szacunek budzi raczej stonowane okazywanie bólu, z czym nie zgadza się autorka $L i$ stó $w^{44}$. Jednocześnie dostrzega on, że jest możliwe niemal automatyczna reakcja na zagrożenie, w którym ktoś się znajduje, czy współodczuwanie na widok czyichś ran.

Zdaniem Smitha, trudniej współodczuwać z jakimikolwiek doznaniami zmysłowymi niż tymi, które mają źródło w wyobraźni. W dodatku - jak twierdzi autor Teorii uczuć moralnych - nawet z zakochaniem trudno jest sympatyzować. Zachwyty nad ukochaną czy ukochanym obserwatorzy uznają za przesadzone i często śmieszne, chociaż samo obserwowanie miłości wywołuje pozytywne wrażenia $^{45}$. Zupełnie inaczej miłość i zakochanie postrzega de Grouchy. Jej zdaniem miłość polega na dawaniu innym szczęścia i zdolne są do niej osoby o szczodrym sercu, ale też wykracza poza przyjaźń - w przypadku zakochania samo wspomnienie twarzy ukochanej osoby wywołuje przyjemność ${ }^{46}$. Myślicielka krytycznie podchodzi do poglądów Smitha dotyczących miłości i zakochania: jej zdaniem miłość

\footnotetext{
${ }^{40}$ Tamże, 58.

${ }^{41}$ Smith, Teoria uczuć moralnych, 57-59.

${ }^{42}$ Tamże, 63.

${ }^{43}$ Tamże, 35-45.

${ }^{44}$ de Grouchy, „Lettres sur la sympathie”, 58-59; Smith, Teoria uczuć moralnych, 40-41.

${ }^{45}$ Smith, Teoria uczuć moralnych, 41-45.

${ }^{46}$ de Grouchy, „Lettres sur la sympathie”, 51-55.
} 
jest uniwersalnie rozumiana (jeśli ktoś jej doświadczył, to potrafi z nią sympatyzować), jest bezwarunkowa, nie trzeba na nią zasługiwać, polega na dawaniu i jest niezwykle ważna, nie może mieć zatem racji filozof uznający miłość romantyczną za uczucie niższe i wspominający o zasługiwaniu na uczucia innych ${ }^{47}$. Przy czym należy pamiętać, że Smith w rzeczywistości docenia rolę miłości, uważa, że miłość do dzieci przychodzi naturalnie, jednak nie rozważa dogłębnie kwestii miłości romantycznej. Zaznacza natomiast, że obserwatorowi trudno podzielać odczucia zakochanych.

De Grouchy uważa, że kiedy u drugiego człowieka widzimy objawy świadczące o tym, że cierpi, możemy dzięki pamięci i wyobraźni przywołać i odczuć to - wytworzone na bazie partykularnego doświadczenia - ogólne uczucie nieszczęścia, które wywołuje w nas ból. Proces ten zachodzi niemalże od razu, naturalnie. Jest to prostsze, gdy w przeszłości sami doświadczyliśmy czegoś podobnego. Obserwując kogoś, kto cierpi, niekiedy nawet można odczuwać ból w odpowiedniej części ciała. De Grouchy przywołuje przykład hipochondryków (obecnych szczególnie wśród klas wyższych, których puste życie nie pozwala na poradzenie sobie z nazbyt silnie działającą wyobraźnią), którym wystarczy przeczytanie o objawach choroby, by odczuwać ból ${ }^{48}$. Jak zresztą twierdzi myślicielka, krytykując współczesną sobie arystokrację, bogaci rzadko doświadczają trosk, ich egoizm, majątek i władza dystansują ich od tej szkoły, jaką daje odczuwanie nieszczęścia. Markiza Condorcet zwraca również uwagę, że nawyk i doświadczenie niekiedy osłabiają uczucia - i ból, i przyjemność odczuwa się silniej, jeśli kontrastują z przeciwnym stanem $^{49}$. To właśnie doznawanie bólu jest źródłem sympatii i sprawia, że stajemy się bardziej ludzcy ${ }^{50}$ : „pierwsze przyczyny sympatii wywodzą się z natury odczuć, których doświadczenia powodują w nas przyjemność i ból, przede wszystkim, jako istoty odczuwające, jesteśmy zdolni do sympatii z fizycznymi dolegliwościami, które są najczęstszymi ludzkimi nieszczęściami [...]. Czegóż nie zawdzięczamy sympatii, nawet w jej najsłabszych przejawach, skoro już od tego momentu sympatia jest pierwszą przyczyną uczucia ludzkości (sentiment d'humanité, feeling of humanity), którego skutki są tak cenne. Kompensuje ono część zła rodzącego się

\footnotetext{
${ }^{47}$ Dawson, „Love, Marriage and Virtue”, 30-31, 37; Brown, „Introduction”, 61-62.

${ }^{48}$ de Grouchy, „Lettres sur la sympathie”, 33.

${ }^{49}$ Tamże, 94.

${ }^{50}$ Tamże, 33-34.
} 
z interesu własnego w dużych społeczeństwach" ${ }^{51}$. To zatem sympatia, oparta na fizycznych doświadczeniach, pozwala funkcjonować społecznościom.

Adam Smith przyjmuje, że najsilniej współodczuwamy z tymi, którzy są nam najbliżsi - dziećmi, rodziną, przyjaciółmi, sąsiadami, potem członkami społeczności, w której żyjemy ${ }^{52}$. Jego zdaniem, wychowywanie się z kimś, przebywanie z nim na co dzień pozwala lepiej poznać i zrozumieć taką osobę, łatwiej też będzie się postawić na jej miejscu, gdy przyjdzie nam z nią współodczuwać. Więź emocjonalna, która łączy bliskich sobie ludzi jednocześnie ułatwia sympatyzowanie, ale też utrudnia bezstronne wydawanie ocen moralnych - tych, których lubimy i kochamy chcemy oceniać łagodniej. Autor Teorii uczuć moralnych wprowadza kategorię naturalnej sympatii, żywionej wobec najbliższych, ale też wobec bogatych i możnych, w niemal automatyczny sposób obdarzając ich ciepłymi uczuciami i szacunkiem. Wraz z kolejnymi wydaniami Teorii, Smith stawał się coraz bardziej krytyczny wobec możnych, nadal jednak uważał, że odebranie monarsze władzy sprawia, iż obserwatorowi jest szkoda króla, który utracił swą pozycję ${ }^{53}$.

W Listach o sympatii możemy znaleźć uwagi krytyczne dotyczące tych poglądów Szkota. Zdaniem de Grouchy, władcom współczujemy bardziej niż reszcie ludzi, ponieważ wydaje się, że ich pozycja powinna chronić ich przed doświadczaniem nieszczęść, a zatem będą oni bardziej wrażliwi na przeciwności losu, nie zaś z powodu ich wielkości, czy dbałości o ich szczęście ${ }^{54}$. Jej zdaniem, jesteśmy zdani na innych ludzi już od urodzenia i ta zależność jest ważnym aspektem relacji międzyludzkich. Cierpienie tych, na których polegamy, porusza bardziej niż bolączki tych, $\mathrm{z}$ którymi nie wchodzimy w tego typu relacje. Dalej sympatia rozciąga się na innych, tych, którzy mogą być wsparciem, a wreszcie na tych, z którymi po prostu lubimy przebywać. Ten specyficzny rodzaj sympatii przypomina naturalną sympatię opisywaną przez Smitha, nie wyróżnia jednak bogatych i możnych, ograniczając się jedynie do bliskich.

Sympatia jest zatem, jak widać to w Listach, „głęboko zanurzona w naszej naturze" 55 . Już malutkie dzieci sympatyzują z innymi, są w stanie dostrzegać ich

${ }^{51}$ de Grouchy, „Lettres sur la sympathie”, 36-37.

${ }^{52}$ Smith, Teoria uczuć moralnych, 324-338; Fonna Forman-Barzilai, Circles of Sympathy. Cosmopolitanism and Moral Theory (Cambridge: Cambridge University Press, 2010).

${ }^{53}$ Smith, Teoria uczuć moralnych, 76-78.

${ }^{54}$ de Grouchy, „Lettres sur la sympathie”, 57.

${ }^{55}$ Brown, „Introduction”, 4. 
ból i zmiany nastroju. Pierwsze więzi oparta na sympatii, zdaniem de Grouchy, powstają między malutkim dzieckiem a jego opiekunami. Myślicielka podkreśla rolę edukacji: ma ona uwrażliwiać i uczyć używania rozumu, wyciągania wniosków, zdolności do abstrakcji, dążenia do prawdy, zauważania szerszego kontekstu, rozumienia reguł moralnych i społecznych, a nie uczenia się na pamięć. Autorka Listów uważa, że rodzice i nauczyciele są odpowiedzialni za utrzymanie i rozwijanie w dzieciach wrażliwości i zdolności do refleksji, nauczenie ich, jak sympatyzować ze światem ${ }^{56}$. Rolą dorosłych jest wzmocnienie tej naturalnej zdolności do sympatyzowania, którą można u dzieci zaobserwować; rodzice powinni się skupić na uczuciach, wrażliwości i szczęściu pociech, nie zaś na trosce o ich pozycję, zawód i rozwój talentów ${ }^{57}$. To przecież dzięki sympatii właśnie chcemy oszczędzić innym cierpienia i nabieramy wrażliwości na ich krzywdę. Sympatyzowanie z innymi może stać się pewnego rodzaju nawykiem, opiera się przecież na powtarzalnym doświadczeniu, działaniu wyobraźni i pamięci. Dlatego, aby lepiej współodczuwać, możemy próbować wzmocnić wspomnienia i działanie wyobraźni ${ }^{58}$.

Myślicielka krytykuje także Smitha za to, że nie wyprowadza pojęcia sprawiedliwości (just/unjust) z rozumu, tylko z ogólnych zasad moralności (general rules) i zakłada istnienie zmysłu wewnętrznego (sens intime, w angielskim tłumaczeniu: internal sense) bez zdefiniowania go, tym samym traktując go jako wyjaśnienie dla rzeczy, których wytłumaczyć nie umiemy ${ }^{59}$.

Znaczącym odejściem od Teorii uczuć moralnych jest wprowadzone w Listach o sympatii rozróżnienie na sympatię partykularną i ogólną (sympathie individuelle et générale $)^{60}$. Pierwszą z nich, „.....] tak długo uznawano za niewytłumaczalną, a jest jednakże niczym więcej, jak tylko naturalnym efektem naszej

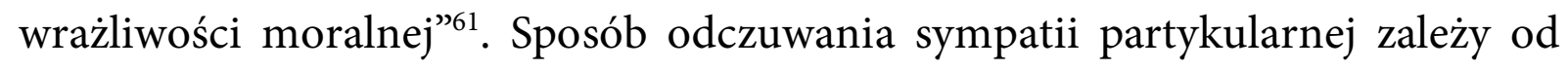

\footnotetext{
${ }^{56}$ Deidre Dawson, „Is Sympathy so Surprising? Adam Smith and French Fictions of Sympathy”, Eighteenth-Century Life 15, nr 1-2 (1991): 159.

${ }^{57}$ de Grouchy, „Lettres sur la sympathie”, 35.

${ }^{58}$ Broadie, Agreeable Connexions, 154.

${ }^{59}$ de Grouchy, „Lettres sur la sympathie”, 84-86.

${ }^{60}$ Tamże, 47.

${ }^{61}$ Tamże, 48.
} 
wielu czynników, jak wyjaśnia de Grouchy, wśród nich od siły wyobraźni i wrażliwości oraz od refleksji ${ }^{62}$. Jest silniejsza wśród ludzi delikatnych i czystych, którym łatwiej nawiązać więź z innymi. To jej właśnie zawdzięczamy budowanie więzi międzyludzkich i możliwość osiągnięcia szczęścia. Sympatia ogólna natomiast wyłania się $\mathrm{w}$ „ [...] procesie generalizowania sympatii, który prowadzi od sympatii przed-refleksyjnej do sympatii partykularnych i od nich do sympatii ogólnej, która stanowi prawdziwe uczucie moralne"63. Podążając za sympatią partykularną, niemal instynktownie działamy w sposób zgodny z naszym sercem i wiemy, co wybrać. W przypadku sympatii ogólnej różne opcje, między którymi przychodzi nam decydować, często wydają się równoważne ${ }^{64}$.

\section{Podsumowanie}

Listy o sympatii Sophie de Grouchy rozpoczynają się od dostrzeżenia braków w rozważaniach Adama Smitha. Sama myślicielka nie referuje jednak poglądów autora Teorii uczuć moralnych i nie ogranicza się do przedstawienia krytyki. Jej uwagi podnoszą problem źródeł sympatii, ze szczegółowym opisem dostrzegania bólu innych jako podstawy do uczenia się sympatyzowania. Przedstawia ona także podział sympatii na partykularną i ogólną, a następnie buduje argumentację podkreślającą rolę edukacji oraz krytykuje istniejące instytucje. Filozofia Sophie de Grouchy znacząco wychodzi poza bycie komentarzem, dodatkiem czy uzupełnieniem rozważań Adama Smitha. Myślicielka nie tylko próbuje uzupełnić istniejącą, jej zdaniem, istotną lukę w badaniach Smitha, ale też przedstawia wyniki własnych rozważań, niekiedy wyraźnie rozbieżne z poglądami autora Teorii uczuć moralnych. Niewątpliwie autorka Listów o sympatii przedstawiła własną koncepcję filozoficzną, często w opozycji do poglądów Szkota.

Sophie de Grouchy nie tylko ma inny punkt wyjścia niż Smith (uzupełnienie wyraźnie, jej zdaniem, istniejącej luki w Teorii uczuć moralnych), ale i inny cel. Smith opisuje działanie sympatii, bogato ilustrując jej różne przejawy. Dostrzega

${ }^{62}$ Tamże, 50.

${ }^{63}$ Dumouchel, „Une éducation sentimentale”, 145. W artykule Dumouchela można znaleźć pogłębioną analizę przejścia od sympatii partykularnej do uczuć ogólnych.

${ }^{64}$ de Grouchy, „Lettres sur la sympathie”, 73. 
jej kluczową rolę w budowaniu i utrwalaniu harmonii społecznej. De Grouchy natomiast, pisząc o sympatii, widzi w niej narzędzie zmiany społecznej, budowy wrażliwości i moralności ludzi, sposób na przebudowę istniejących, wadliwych jej zdaniem, instytucji. Jak zauważył Michaël Biziou: Listy o sympatii „[...] w efekcie proponują program reformy socjalne - na polu polityki, prawa i edukacji - który znacząco oddala się od oryginalnych zagadnień Teoriï ${ }^{65}$.

Myślicielka używa pojęć charakterystycznych dla teorii Smitha - pisze o sympatii, wyobraźni, nawyku i doświadczeniu. Jednakże niekiedy rozumie je w inny sposób, wprowadza własne rozróżnienia, osadza je w ramach własnych poglądów. W efekcie buduje filozofię znacząco różniącą się od tej wyrażonej w Teorii uczuć moralnych. Nie oznacza to jednak, że zupełnie nie zgadza się ze Smithem: oboje podkreślają, jak ważna jest jednostka i doceniają rolę wolności ${ }^{66}$. Oboje skupiają się na roli uczuć, sympatii, rozumu i wyobraźni w sądach moralnych i rozwoju moralności, a także uznają, że doświadczenie i wychowanie odgrywa istotną rolę.

\section{Bibliografia}

Źródła

de Grouchy, Sophie. Letters on Sympathy. Philadelphia: American Philosophical Society, 2008. de Grouchy, Sophie. „Lettres sur la sympathie”. W: Les 'Lettres sur la sympathie' (1798) de Sophie de Grouchy, marquise de Condorcet, red. Marc André Bernier i Deidre Dawson. Oxford: Voltaire Foundation, 2010.

Smith, Adam. Teoria uczuć moralnych. Tłum. Danuta Petsch. Warszawa: PWN, 1989. Smith, Adam. The Theory of Moral Sentiments. Indianapolis: Liberty Fund, 1982.

\section{Opracowania}

Bernier, Marc André i Deidre Dawson, red. Les 'Lettres sur la sympathie' (1798) de Sophie de Grouchy, marquise de Condorcet. Oxford: Voltaire Foundation, 2010.

${ }^{65}$ Biziou, „French translations and re-translations,” 59. Por. też uwagi Deidre Dawson („Is Sympathy so Surprising?," 161).

${ }^{66}$ Emma Rothschild, Economic Sentiments. Adam Smith, Condorcet, and the Enlightenment (Cambridge, MA: Harvard University Press, 2001), 70. 
Biziou, Michaël. „French translations and re-translations of Smith's Theory of Moral Sentiments: the unbearable lightness of (re)translating". Adam Smith Review 8 (2015): 53-80. DOI: https://doi.org/10.4324/9781315737195.

Broadie, Alexander. Agreeable Connexions: Scottish Enlightenment Links with France. Edinburgh: Birlinn, 2012.

Brown, Karin. „Introduction: The Letters, Their Author, and Her Times”. W: Sophie de Grouchy, Letters on sympathy (1798): a critical edition, red. Karin Brown, XI-XXXIX. Philadelphia: American Philosophical Society, 2008.

Deidre, Dawson. „Is Sympathy so Surprising? Adam Smith and French Fictions of Sympathy”. Eighteenth-Century Life 15, nr 1-2 (1991): 147-162.

Deidre, Dawson. „Love, Marriage and Virtue: Mary Wollstonecraft and Sophie de Grouchy, marquise de Condorcet, Respond to The Theory of Moral Sentiments'. Adam Smith Review7 (2014): 24-46.

Dumouchel, Daniel. „Une éducation sentimentale: sympathie et construction de la morale dans les Lettres sur la sympathie de Sophie de Grouchy". W: Les 'Lettres sur la sympathie' (1798) de Sophie de Grouchy, marquise de Condorcet, red. Marc André Bernier i Deidre Dawson, 139-150. Oxford: Voltaire Foundation, 2010.

Forman-Barzilai, Fonna. Circles of Sympathy. Cosmopolitanism and Moral Theory. Cambridge: Cambridge University Press, 2010.

Griswold Jr., Charles L. Adam Smith and the Virtues of Enlightment. Cambridge: Cambridge University Press, 2009. DOI: 10.1017/CBO9780511608964.

Guillois, Antoine. La Marquise de Condorcet. Sa Famille, son Salon, ses Amis 1764-1822. Paryż: Paul Ollendorff, 1897.

Muller, Hans D. „Sympathy for whom? Smith's reply to Hume”. Journal of the American Philosophical Association 2, nr 2 (2016): 212-232. DOI: 10.1017/apa.2016.15.

Otteson, James R. Adam Smith's Marketplace of Life. Cambridge: Cambridge University Press, 2002.

Pisanelli, Simona. „Adam Smith and the Marquis de Condorcet. Did they really meet?”. Iberian Journal of History of Economic Thought 2, $\mathrm{nr} 1$ (2015): 21-35. DOI: 10.5209/rev_IJHE.2015.v2.n1.49771.

Rothschild, Emma. Economic Sentiments. Adam Smith, Condorcet, and the Enlightenment. Cambridge, MA: Harvard University Press, 2001.

Seth, Catriona. „Sophie de Grouchy-Condorcet's translation of Adam Smith's Theory of Moral Sentiments". Adam Smith Review7 (2014): 18-23. DOI: 10.4324/9780203070727.

Seth, Catriona. „Un double service rendu à la postérité: la Théorie des sentiments moraux par Adam Smith, suivie des Lettres sur la sympathie”. W: Les 'Lettres sur la sympathie'(1798) de Sophie de Grouchy, marquise de Condorcet, red. Marc André Bernier i Deidre Dawson, 127-137. Oxford: Voltaire Foundation, 2010. 


\section{Summary}

\section{Sophie de Grouchy: philosophy based on dispute}

The article portrays Sophie de Grouchy (1764-1822) who translated Adam Smith's Theory of Moral Sentiments into French adding eight letters, Lettres sur la Sympathie, with her own comments on his work. The Lettres engage critically with Smith's philosophical analysis of sympathy. They also present her criticism of institutions and views on other matters including philosophy. The latter are in many instances in variance with those preached by Smith.

Keywords: Sophie de Grouchy, Adam Smith, sympathy

\section{Zusammenfassung}

Sophie de Grouchy: die auf Polemik beruhende Philosophie

Sophie de Grouchy übersetzte Theorie der ethischen Gefühlevon Adam Smith ins Französische. Sie fügte ihrer Übersetzung Lettres sur la Sympathie bei, in denen sie auf den grundsätzlichen Mangel im Werk von Smith hingewiesen hatte: die mangelnde Erklärung der Quelle der Sympathie. Ihre Lettres legen nicht nur die Anschauungen der Denkerin im Hinblick auf diese Frage dar, sie enthalten auch ihre Überlegungen zum Thema der Sympathie, die Institutionskritik usw. Der Artikel setzt sich zum Ziel, die Denkerin de Grouchy darzustellen, ihre Theorie der Sympathie zu charakterisieren und nachzuweisen, dass Lettres nicht nur ein Kommentar zu Theorie von Smith sind, sondern auch entgegengesetzte philosophische Anschauungen enthalten.

Schlüsselworte: Sophie de Grouchy, Adam Smith, Sympathie

Information about Author:

ANNA MARKWART, PhD., Institute of Philosophy, Nicolaus Copernicus University in Torun, Poland; address for correspondence: Instytut Filozofii UMK, Fosa Staromiejska 1a, PL 87-100 Toruń; e-mail: markwart.anna@gmail.com 